\title{
Subsequent Trial Activity
}

National Cancer Institute

\section{Source}

National Cancer Institute. Subsequent Trial Activity. NCI Thesaurus. Code C82511.

An indication or description of the next trial activity. 